\title{
Gender-specific relationship between serum free and total IGF-I and bone mineral density in elderly men and women
}

\author{
J A M J L Janssen ${ }^{1}$, H Burger ${ }^{2}$, R P Stolk ${ }^{2,3}$, D E Grobbee ${ }^{2,3}$, F H de Jong ${ }^{1}$, S W J Lamberts ${ }^{1}$ and H A P Pols ${ }^{1,2}$ \\ ${ }^{1}$ Department of Internal Medicine III, Erasmus University, Rotterdam, The Netherlands, ${ }^{2}$ Department of Epidemiology and Biostatistics, Erasmus \\ University, Rotterdam, The Netherlands and ${ }^{3}$ Julius Center for Patient Oriented Research, Utrecht University, Utrecht, The Netherlands \\ (Correspondence should be addressed to J A M J L Janssen, Department of Internal Medicine III, Room D438, University Hospital Dijkzigt, \\ Dr Molewaterplein 40, 3015 GD Rotterdam, The Netherlands)
}

\begin{abstract}
Objective: Little is known about the association between free IGF-I levels and bone mineral density (BMD).

Design: A cross-sectional study of 218 healthy subjects (103 men, 115 women, age 55-80 years) was carried out.

Methods: Fasting serum free IGF-I, total IGF-I, estradiol and sex hormone-binding globulin (SHBG) levels were measured. The ratio of estradiol to SHBG was used as an index of free estradiol. BMD measurements were performed by dual-energy X-ray absorptiometry of the lumbar spine and the proximal femur.

Results: In multivariate analyses with BMD of the lumbar spine as the dependent variable and serum free IGF-I, age, body mass index (BMI) and the free estradiol index as independent variables, the free IGF-I was positively related to the BMD of the lumbar spine in men $(P=0.02)$ but not in women. When the same analyses for the lumbar BMD were performed with total serum IGF-I the association was also only statistically significant in men $(P=0.05)$. In multivariate analyses with the trochanter BMD as the dependent variable and serum free IGF-I, total IGF-I, age, BMI and the free estradiol index as independent variables, the associations between (free and total) IGF-I and the trochanter BMD in men was of borderline significance.

Conclusions: In elderly men free and total IGF-I were positively related to lumbar BMD, while (free and total) IGF-I was borderline positively related to trochanter BMD. As these relationships were not observed in elderly women, we suggest a weak gender-specific anabolic effect of IGF-I on BMD on trabecular bone.
\end{abstract}

European Journal of Endocrinology 138 627-632

\section{Introduction}

Insulin-like growth factor-I (IGF-I) and its specific insulin-like growth factor-binding proteins (IGFBPs) are postulated to play a key role in bone metabolism (1). It is generally agreed that IGF-I has anabolic effects on bone cells (2). It has been shown to be an important regulator of bone remodeling and growth (3) and has been found to stimulate collagen synthesis in bone, resulting in increased matrix production (4). Bone cells synthesize IGF-I and all of the six IGFBPs (1) and observations in osteoblast-like cell lines have suggested that skeletal concentration of IGF-I is a reflection of its local synthesis by osteoblasts (3).

Recently a method was developed to measure free serum IGF-I $(5,6)$. Free IGF-I, analogous to free sex and adrenal steroids and thyroid hormones, is likely to be a major biologically active hormonal form of IGF-I (7).

Estrogens have a protective effect on bone mass and slow bone loss during aging (8). Moreover, it has been suggested that the estrogen status in women has a complex effect on serum concentrations of IGF-I and therefore has to be taken into account when evaluating levels of serum IGF-I (9).

In order to gain more insight into the relationships between systemic IGF-I, estrogens and bone mineral density (BMD) in the elderly, we measured serum free and total IGF-I levels, estrogens and BMD in 218 healthy elderly subjects.

\section{Materials and methods Study population}

The population for the present study included 218 subjects aged 55 to 80 years, who had completed the baseline visit of the Rotterdam Study not more than 6 months earlier. The Rotterdam Study is a populationbased prospective cohort study of determinants of chronic disabling diseases in the elderly and has been 
described elsewhere (10). Briefly, all 10275 inhabitants of a suburb of Rotterdam, aged 55 years and over, were invited to participate. From the 9161 independently living persons $77 \%$ participated in the interview and $71 \%$ also had extensive examinations including bone density measurements.

The 218 people who took part in the present study were randomly selected from the 7983 participants of the Rotterdam Study after exclusion of subjects with acute psychiatric disease or diabetes. Compared with the other participants of the Rotterdam Study without known diabetes mellitus, there were no differences in age and gender distribution, mean blood pressure, use of antihypertensive drugs, echocardiographic evidence of atherosclerotic plaques in the carotid arteries and electrocardiographic abnormalities. Only four women in this study population were on hormone replacement therapy. These four women were excluded from analysis. Informed consent was obtained from all subjects and the study was approved by the medical ethics committee of Erasmus University Medical School.

\section{Measurements}

Biochemical measurement Participants were examined in the morning after an overnight fast. Fasting blood samples were taken by venipuncture between 0800 and $0900 \mathrm{~h}$ and allowed to coagulate for $30 \mathrm{~min}$. Subsequently serum was separated by centrifugation and quickly frozen in liquid nitrogen. Free IGF-I was measured with a commercially available two-site IRMA (Diagnostic System Laboratories Inc., Webster, TX, USA; intra-assay and inter-assay coefficients of variation (CV) were 10.3 and $10.7 \%$ respectively) $(5,6)$.

The free IGF-I assay needs no initial sample extraction as part of the standard procedure to measure IGF-I. Samples are added directly to tubes containing a dense coating of high-affinity free IGF-I antibody, incubated for $2 \mathrm{~h}$ at room temperature, washed, incubated with ${ }^{125}$ I-labeled antibody directed to a second epitope, washed and counted. There was no cross-reactivity with IGF-II and no residual IGFBP-1 or IGFBP-3 was detected after the first wash. It is likely that the free IGF-I fraction measured with the free IGF-I assay is a combination of the true free and the fraction of IGF-I which can be readily dissociated from IGFBPs under the specific assay conditions (5). Total IGF-I was determined by a commercially available RIA (Medgenix Diagnostics, Brussels, Belgium; intra-assay and inter-assay CV 6.1 and $9.9 \%$ ) after an acidification/neutralization step. The purpose of this step was to convert the different forms of IGF-I present into free IGF-I.

Estradiol was assayed with an RIA (Diagnostic Products Corporation, Los Angeles, CA, USA; intra-assay and inter-assay CV 7.0 and 8.1\%). Sex hormone-binding globulin (SHBG) was assayed with a commercially available IRMA (Diagnostic Products Corporation; intra-assay and inter-assay CV 3.6 and 6.9\%). The ratio of estradiol to SHBG was used as an index of free estradiol (11). Height and weight were measured wearing indoor clothes and without shoes. Body mass index (BMI) was defined as weight divided by the square of height $\left(\mathrm{kg} / \mathrm{m}^{2}\right)$.

Measurement of BMD BMD measurements were performed by dual-energy X-ray absorptiometry, using a Lunar DPX-L densitometer (Lunar Radiation Corporation, Madison, WI, USA). Standard positioning was used with anterior-posterior scans of the lumbar spine and the right proximal femur. If there was a history of hip fracture or prothesis implantation, the left femur was scanned. Using standard software the vertebrae L2 to L4, and at the proximal femur, the femoral neck, Ward's triangle and the greater trochanter were analyzed. Quality assurance included calibration with the standard of the machine and was performed routinely every morning. The in vivo $\mathrm{CV}$ for BMD measurements was $0.9 \%$ in the lumbar spine, $3.2 \%$ in the femoral neck, $3.1 \%$ in the Ward's triangle, and $2.5 \%$ in the greater trochanter.

Statistical analysis Pearson's correlation coefficients were calculated to assess the associations between IGF-I and BMD, after adjustment for age, and other confounders when appropriate. Analyses in which the values were logarithmically transformed yielded results similar to those with untransformed data. Because interpretation of results from logarithmically transformed data is more difficult, the non-transformed results are presented. Linear regression analysis was used to calculate the statistical significance of differences in general characteristics between men and women, as well as the associations between IGF-I and BMD, after adjustment for age, and other confounders when appropriate. A two-sided $P$ value of $<0.05$ was considered significant. All statistical analyses were performed with a Stata statistical package (Computing Resource Center, Santa Monica, CA, USA).

\section{Results}

In Table 1 general characteristics of the study population are presented. Men were slightly older than women. Mean (free and total) IGF-I levels did not differ between the sexes. BMD was (age-adjusted) higher in men than in women at all four measured sites. Mean free estradiol index was significantly higher in men than in women.

Serum free IGF-I was positively associated with total IGF-I ( $r=0.35, P<0.001)$. Serum total IGF-I decreased with age in women, while this relationship just missed significance in men (Table 2). Free IGF-I was not related to age in either sex (Table 2). Free IGF-I was inversely related to BMI in men, but this relationship was lost after adjustment for age. Total IGF-I was not significantly related to BMI in either sex (Table 2). 
Table 1 Distribution of variables by sex (mean \pm S.E.M.).

\begin{tabular}{|c|c|c|c|}
\hline & $\begin{array}{c}\text { Men } \\
(n=103)\end{array}$ & $\begin{array}{l}\text { Women } \\
(n=111)\end{array}$ & $\boldsymbol{P}$ \\
\hline $\begin{array}{l}\text { Age (years) } \\
\text { BMI }\left(\mathrm{kg} / \mathrm{m}^{2}\right)\end{array}$ & $\begin{array}{l}67.6 \pm 0.6 \\
26.4 \pm 0.3\end{array}$ & $\begin{array}{l}65.9 \pm 0.6 \\
26.6 \pm 0.4\end{array}$ & $\begin{array}{l}0.05 \\
0.70^{* *}\end{array}$ \\
\hline $\begin{array}{l}\text { Total IGF-I* }(\mathrm{nmol} / \mathrm{l}) \\
\text { Free IGF-I* }(\mathrm{nmol} / \mathrm{l})\end{array}$ & $\begin{array}{c}19.3 \pm 0.83 \\
0.088 \pm 0.005\end{array}$ & $\begin{array}{c}17.9 \pm 0.70 \\
0.095 \pm 0.005\end{array}$ & $\begin{array}{l}0.11^{* *} \\
0.22^{* *}\end{array}$ \\
\hline $\begin{array}{l}\mathrm{SHBG}^{*}(\mathrm{nmol} / \mathrm{l}) \\
\text { Estradiol* }(\mathrm{pmol} / \mathrm{l}) \\
\text { Free estradiol index }(\mathrm{pmol} / \mathrm{nmol})\end{array}$ & $\begin{aligned} 50.9 & \pm 2.0 \\
106.4 & \pm 17.2 \\
2.26 & \pm 0.25\end{aligned}$ & $\begin{array}{l}60.2 \pm 2.7 \\
82.1 \pm 4.8 \\
1.65 \pm 0.13\end{array}$ & $\begin{array}{l}0.006^{* \star} \\
0.10^{* *} \\
0.009^{\star \star}\end{array}$ \\
\hline $\begin{array}{l}\text { BMD }\left(\mathrm{g} / \mathrm{cm}^{2}\right) \\
\text { Lumbar spine } \\
\text { Femoral neck } \\
\text { Ward's triangle } \\
\text { Greater trochanter }\end{array}$ & $\begin{array}{l}1.19 \pm 0.02 \\
0.87 \pm 0.01 \\
0.71 \pm 0.02 \\
0.83 \pm 0.01\end{array}$ & $\begin{array}{l}1.03 \pm 0.02 \\
0.81 \pm 0.01 \\
0.73 \pm 0.01 \\
0.73 \pm 0.01\end{array}$ & $\begin{array}{r}<0.001^{* *} \\
0.003^{* *} \\
0.027^{\text {** }} \\
<0.001^{\text {** }}\end{array}$ \\
\hline
\end{tabular}

${ }^{*}$ Fasting values.

** Difference between men and women, adjusted for age.

No (age-adjusted) relationships were present between serum free IGF-I and the free estradiol index in either sex (men: $r=0.13, P=0.21$; women: $r=0.16, P=0.10$ ). Total serum IGF-I was (age-adjusted) positively related to free estradiol index in men and women (men: $r=0.24, P=0.02$; women: $r=0.26, P=0.008)$.

$\mathrm{BMD}$ at all four measured sites was (age-adjusted) significantly related to BMI (lumbar: $r=0.33$; trochanter: $r=0.36$; femoral neck: $r=0.38$; Ward's triangle: $r=0.36$; $P$ in all four sites $<0.001)$. Similar relationships between BMD and BMI were observed when men and women were analyzed separately (data not shown).

No relationships were observed in the total study population between free or total IGF-I, and the BMD of the lumbar spine, femoral neck, Ward's triangle and the greater trochanter respectively, without further adjustments. To give an impression of the distribution of the data the relationships between (total and free) IGF-I and the lumbar spine and between (total and free) IGF-I

Table 2 Association between fasting total and free IGF-I levels and age and $\mathrm{BMI}$.

\begin{tabular}{llll}
\hline Variable* $^{*}$ & Sex & $\boldsymbol{r}$ & $\boldsymbol{P}$ \\
\hline Total IGF-I & & & \\
Age & Men & -0.17 & 0.09 \\
& Women & -0.28 & 0.003 \\
Free IGF-I & & & \\
Age & Men & 0.14 & 0.15 \\
& Women & 0.10 & 0.27 \\
BMI & & & \\
Total IGF-I & Men & -0.003 & 0.97 \\
Free IGF-I & Women & 0.09 & 0.35 \\
& Men & -0.20 & 0.05 \\
& Women & -0.004 & 0.94 \\
\hline
\end{tabular}

* Dependent variable is underlined. and the greater trochanter are showed in Figs 1 and 2 . Only in men were free IGF-I and total IGF-I significantly associated with BMD of the lumbar spine after adjustment for BMI and age (Table 3). The relationship between both free IGF-I and total IGF-I respectively, and trochanter BMD in men reached borderline significance after the same adjustments. In multivariate analyses with BMD of the lumbar spine as the dependent variable and free IGF-I, age, BMI and the free estradiol index as independent variables, the association between free IGF-I and the BMD of the lumbar spine in men remained statistically significant $(r=0.24, P=0.02)$. When the same analyses for the lumbar BMD were performed with total IGF-I rather than free IGF-I, the association was statistically significant in men $(r=0.21, P=0.05)$. In

Table 3 Associations between BMD at various sites and fasting total and free IGF-I levels in men and women*.

\begin{tabular}{|c|c|c|c|c|}
\hline \multirow[b]{2}{*}{ Variable* } & \multicolumn{2}{|c|}{ Men } & \multicolumn{2}{|c|}{ Women } \\
\hline & $r$ & $P$ & $r$ & $P$ \\
\hline Lumbar spine & & & & \\
\hline $\begin{array}{l}\text { Total IGF-I } \\
\text { Free IGF-I }\end{array}$ & $\begin{array}{l}0.22 \\
0.24\end{array}$ & $\begin{array}{l}0.03 \\
0.02\end{array}$ & $\begin{array}{l}-0.10 \\
-0.009\end{array}$ & $\begin{array}{l}0.35 \\
0.93\end{array}$ \\
\hline $\begin{array}{l}\text { Femoral neck } \\
\text { Total IGF-I } \\
\text { Free IGF-I }\end{array}$ & $\begin{array}{l}0.11 \\
0.09\end{array}$ & $\begin{array}{l}0.29 \\
0.36\end{array}$ & $\begin{array}{l}-0.12 \\
-0.05\end{array}$ & $\begin{array}{l}0.27 \\
0.65\end{array}$ \\
\hline $\begin{array}{l}\text { Ward's triangle } \\
\text { Total IGF-I } \\
\text { Free IGF-I }\end{array}$ & $\begin{array}{l}0.15 \\
0.15\end{array}$ & $\begin{array}{l}0.15 \\
0.14\end{array}$ & $\begin{array}{l}-0.06 \\
-0.04\end{array}$ & $\begin{array}{l}0.56 \\
0.72\end{array}$ \\
\hline $\begin{array}{l}\text { Greater trochanter } \\
\text { Total IGF-I } \\
\text { Free IGF-I }\end{array}$ & $\begin{array}{l}0.19 \\
0.18\end{array}$ & $\begin{array}{l}0.06 \\
0.08\end{array}$ & $\begin{array}{l}0.007 \\
0.02\end{array}$ & $\begin{array}{l}0.94 \\
0.89\end{array}$ \\
\hline
\end{tabular}



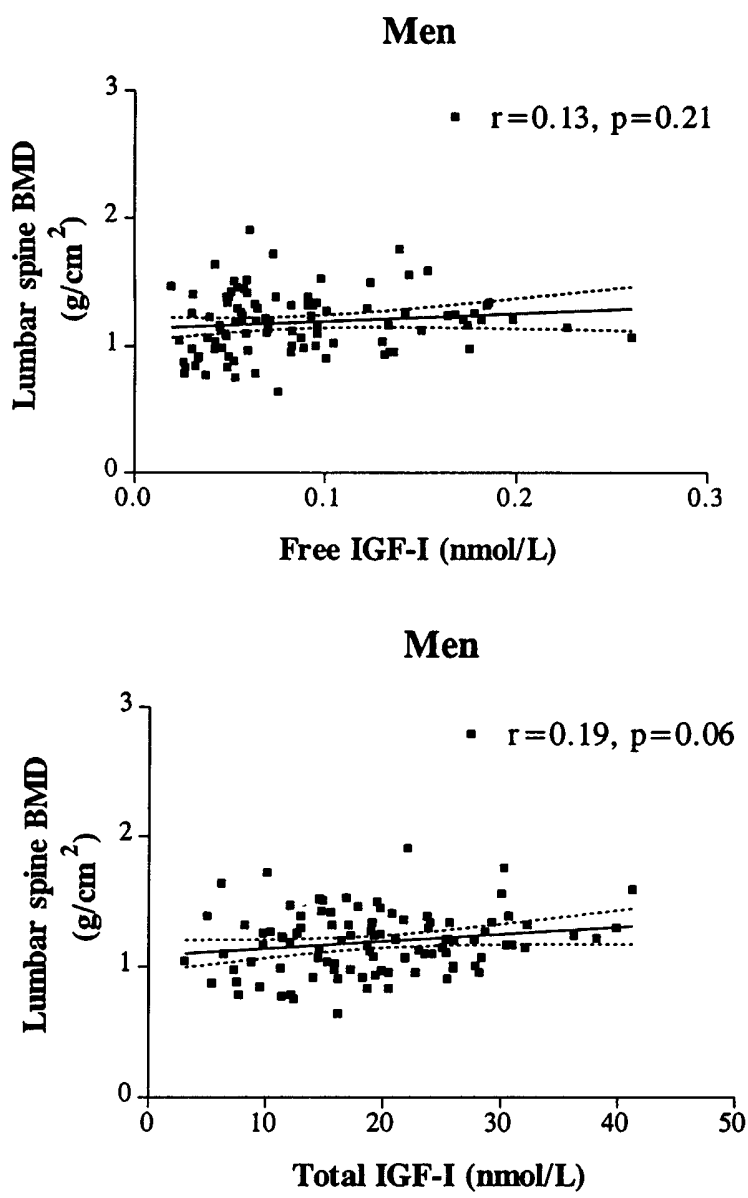
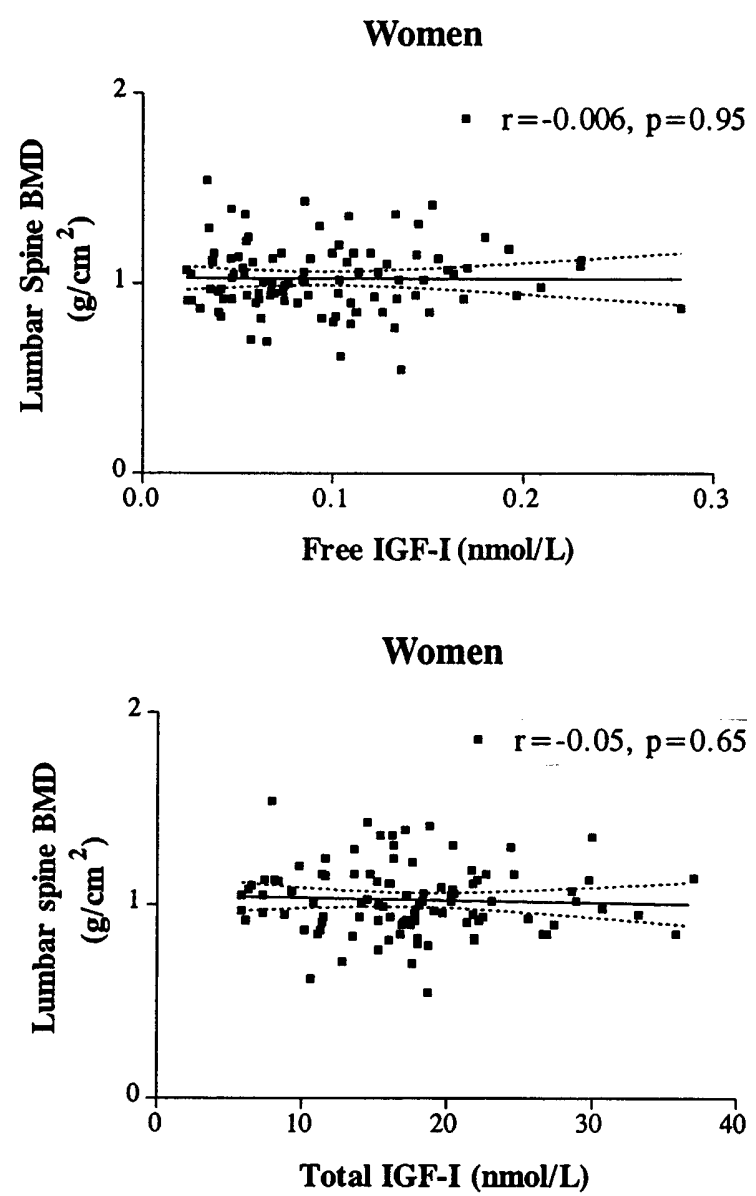

Figure 1 Univariate relationships between (free and total) IGF-I and BMD of the lumbar spine respectively, in men and women. Top: free IGF-I, bottom: total IGF-I. Left: men, right: women. The solid line represents the regression line. The dotted lines represent the $95 \%$ confidence interval.

analyses with the trochanter BMD as the dependent variable and free IGF-I, age, BMI and the free estradiol index as independent variables, the association between free IGF-I and the trochanter BMD in men just missed significance $(r=0.19, P=0.06)$. When the same adjustments were performed for the relationship between the trochanter BMD and total IGF-I, this association remained of borderline statistical significance $(r=0.19$, $P=0.06)$

\section{Discussion}

In this population-derived sample of elderly subjects both free and total IGF-I were weakly positively related to BMD of the lumbar spine in elderly men, but not in women. In men also the relationship between both total and free IGF-I and trochanter BMD reached borderline significance.

These findings suggest that IGF-I levels do not play a major role in protecting the elderly from bone loss with aging. Serum free IGF-I is considered to be the major biologically active hormonal form of IGF-I (7). However, the assessment of serum free IGF-I levels in our study did not give much more additional information than total IGF-I, since the relationships between free IGF-I and total IGF-I and BMD were almost identical.

Previous studies have shown an age-related decrease in the serum level of total and free IGF-I $(7,12)$. Aging is also characterized by a decrease in bone density and a decrease in the IGF-I content of bone (13). Studies on osteoporosis in men have shown a relationship between low bone mass and lower serum IGF-I levels as a consequence of decreased growth hormone secretion $(14,15)$. Other observations suggest that changes in the IGF-I content of bone may be related to changes in serum IGF-I concentration (16), which raises the possibility that the skeletal concentration of IGF-I reflects deposition from serum IGF-I, rather than local production (3). However, the relationship between circulating (free and total) IGF-I levels and the lumbar and trochanter BMD in men, as observed in our study, contributes little to the issue of whether skeletal IGF-I 

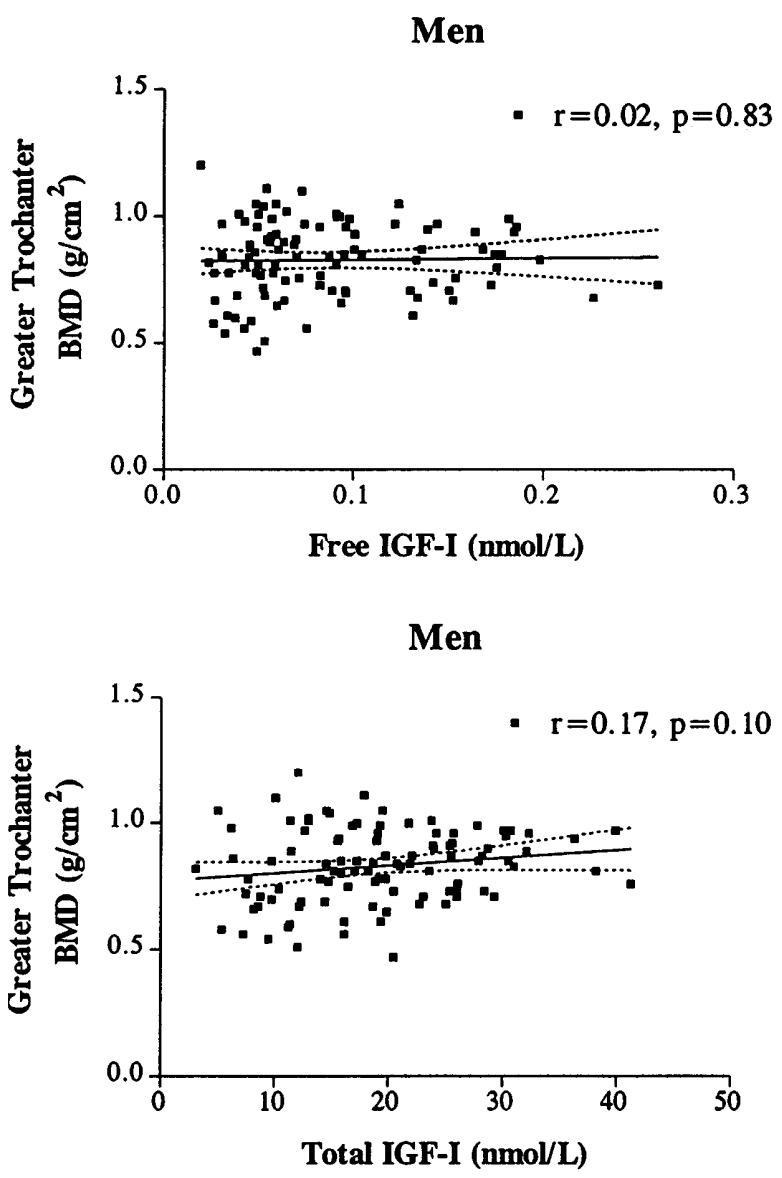
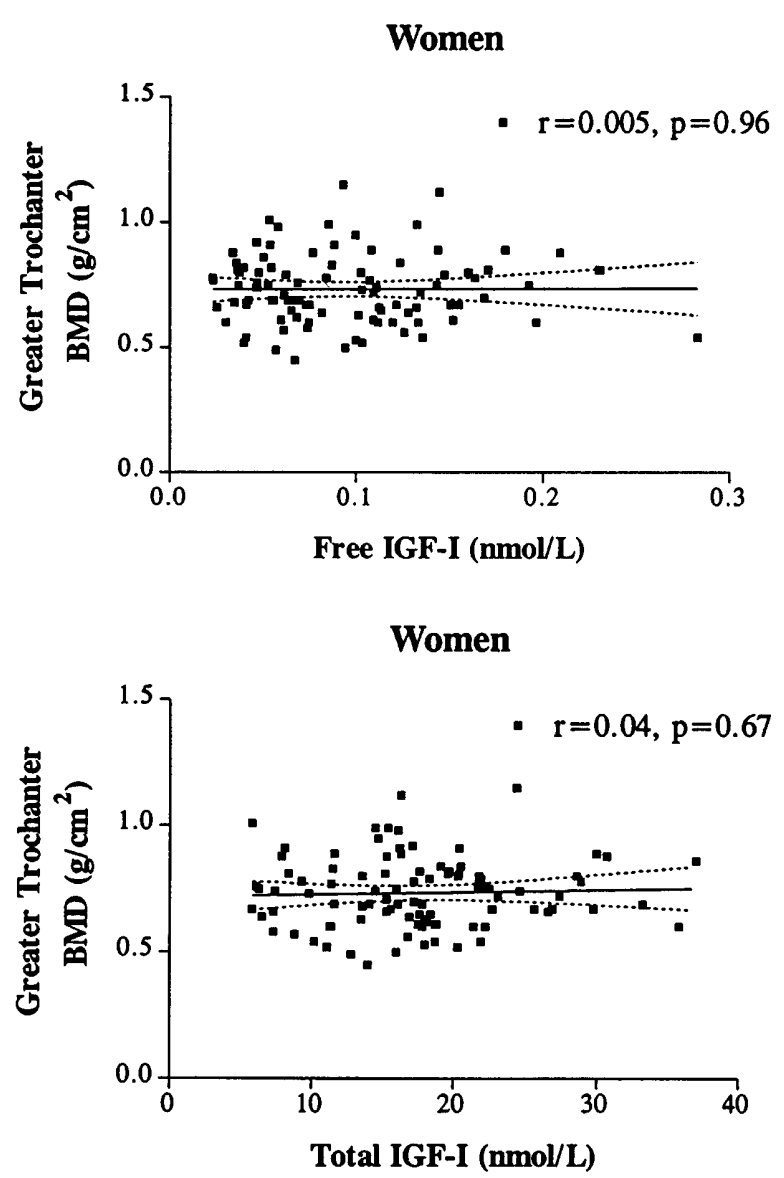

Figure 2 Univariate relationships between (free and total) IGF-I and BMD of the greater trochanter respectively, in men and women. Top: free IGF-I, bottom: total IGF-I. Left: men, right: women. The solid line represents the regression line. The dotted lines represent the $95 \%$ confidence interval.

is predominantly derived from local production or from the circulation. This is still a very complex issue as circulating IGF-I is a marker of growth hormone activity and may simply reflect the direct effects of growth hormone on local skeletal IGF-I production. Moreover, growth hormone and circulating IGF-I may have indirect effects on bone mass, which may have nothing to do with skeletal IGF-I production. For example, there are many interactions between growth hormone/IGF-I and estradiol in men and women and between calcium and growth hormone. The issue is even more complex if one considers that the interindividual differences in skeletal IGF-I concentrations in old age may have already existed when young, and correlations between IGF-I and bone mass may be due to mixtures of genetic and/or environmental influences (17). It is therefore possible that any association between IGF-I and bone mass in elderly individuals may be due to events which occurred long before the actual measurements were performed.

No relationships could be found between free and total IGF-I and BMD in women. This relationship is similar to that reported in postmenopausal women by Kassem et al. (18), Bennett et al. (19) and Rosen et al. (20). Although there are some studies which have shown a positive relationship between BMD and IGF-I in women $(21,22)$, the patients in the study of Pun et al. (21) had also a concomitant vitamin D deficiency, while in the study of Wuster et al. (22) both pre- and postmenopausal women were included in the study. In this latter study there was also a considerable difference in age and body weight between patients and controls. Finally, neither of these studies were population based.

The above mentioned associations between (free and total) IGF-I and (lumbar and trochanter) BMD in men turned out to be present only after adjustment for BMI. It has previously been demonstrated that weight and BMI are some of the strongest predictors of bone mass at all ages in both sexes $(23,24)$, and this effect is especially present at weight-bearing sites such as the lumbar spine and the femur. We observed strong associations between BMD and BMI in both sexes. In men this result might be related to the contribution of lean body mass to BMI, as it has been suggested that 
lean body mass is the principal determinant of BMD in men (25).

In conclusion, a weak positive relationship between serum IGF-I and BMD was observed in men but not in women, possibly indicating a gender-specific anabolic effect of IGF-I on trabecular bone.

\section{Acknowledgement}

This study was supported by a grant from The Netherlands Diabetes Fund.

\section{References}

1 Conover CA, Lee PDK, Riggs BL \& Powell DR. Insulin-like growth factor binding protein-1 expression in cultured human bone cells Regulation by insulin and glucocorticoid. Endocrinology 1996 137 3295-3301.

2 Ravn P, Overgaard K, Spencer EM \& Christiansen C. Insulin-like growth factors I and II in healthy women with and without established osteoporosis. European Journal of Endocrinology 1995 132 313-319.

3 Mohan S, Farley JR \& Baylink DJ. Age-related changes in IGFBP-4 and IGFBP-5 levels in human serum and bone: Implications for bone loss with aging. Progress in Growth Factor Research 19956 465-473.

4 Schmid C, Ernst M, Binz K, Zapf J \& Froesch ER. The endocrine/ paracrine actions of IGFs on bone. In Modern Concepts of Insulinlike Growth Factors, pp 129-141. Ed. EM Spencer. New York: Elsevier Science, 1991.

5 Lee PDK, Powell D, Baker B, Liu F, Mathew G, Levitsky I, Gutierrez OD \& Hintz RL. Characterization of a direct, non-extraction immunoradiometric assay for free IGF-I (Abstract no. 939). Proceedings of the 76th Annual Meeting of the Endocrine Society. Anaheim, 1994, p 435. Bethesda, MD: Endocrine Society Press.

6 Juul A, Flyvbjerg A, Frystyk J, Muller J \& Skakkebæk NE. Serum concentrations of free and total insulin-like growth factor-I, IGE binding proteins- 1 and -3 and IGFBP-3 protease activity in boys with normal or precocious puberty. Clinical Endocrinology 1996 44 515-523.

7 Frystyk J, Skjærbæk C, Dinesen B \& Orskov H. Free insulin-like growth factors (IGF-I and IGF-II) in human serum. FEBS Letters 1994384 185-191.

8 Turner RT, Riggs BL \& Spelsberg TC. Skeletal effects of estrogen. Endocrine Reviews 199415 275-300.

9 Massa G, Igout A, Rombouts L, Frankenne F \& VanderschuerenLodeweyckx M. Effect of oestrogen status on serum levels of growth hormone-binding protein and insulin-like growth factor-I in non-pregnant and pregnant women. Clinical Endocrinology $199339569-575$.

10 Hofman A, Grobbee DE, de Jong PTVM \& van den Ouweland FA. Determinants of disease and disability in the elderly: The Rotterdam elderly study. European Journal of Epidemiology 1991 7 403-422.

11 Khaw K-T, Chir MBB, Tazuke S \& Barett-Connor E. Cigarette smoking and levels of adrenal-androgens in postmenopausal women. New England Journal of Medicine 1988318 1705-1709.
12 Copeland KC, Coletti RB, Devlin JT \& McAuliffe TL. The relationship between insulin-like growth factor-I, adiposity and aging. Metabolism $199039584-587$.

13 Nicolas V, Prewett A, Bettica P, Mohan S, Finkelman RD, Baylink DJ \& Farley JR. Age-related decrease in insulin-like growth factor-I and transforming growth factor- $\beta$ in femoral cortical bone from both men and women: implications for bone loss with aging. Journal of Clinical Endocrinology and Metabolism 199478 10111016.

14 Ljunghall S, Johansson AG, Burman P, Kämpe O, Lindh E \& Karlsson FA. Low plasma levels of insulin-like growth factor I (IGF-I) in male patients with idiopathic osteoporosis. Journal of Internal Medicine 1992 232 59-64.

15 Johansson AG, Burman P, Westermark K \& Ljunghall S. The bone mineral density in acquired growth hormone deficiency correlates with circulating levels of IGF-I. Journal of Internal Medicine $1992232447-452$.

16 Libanati C, Srinivasan N, Baylink DJ, Louis E \& Mohan S. Skeletal size increases during Tanner stages II and III: Association with a marked upregulation of the serum IGF-I system. Journal of Bone and Mineral Research 199510 (Suppl 1) S344.

17 Hong Y, Brismar K, Hall K, Pedersen NL \& de Faire U. Associations between insulin-like growth factor-I (IGF-I), IGF-binding protein1 , insulin and other metabolic measures after controlling for genetic influences: results from middle-aged and elderly monozygotic twins. Journal of Endocrinology 1997153 251-257.

18 Kassem M, Brixen K, Blum W, Mosekilde L \& Eriksen EF. No evidence for reduced spontaneous or growth-hormonestimulated serum levels of insulin-like growth factor (IGF)-I, IGF-II or IGF binding protein 3 in women with spinal osteoporosis. European Journal of Endocrinology 1994131 150-155.

19 Bennett AE, Wahner HW, Riggs BL \& Hintz RL. Insulin-like growth factors I and II: aging and bone density in women. Journal of Clinical Endocrinology and Metabolism 198459 701-704.

20 Rosen C, Donahue LR, Hunter S, Holick M, Kavookjian H, Kirschenbaum A, Mohan S \& Baylink DJ. The 24/25-kDa serum insulin-like growth factor-binding protein is increased in elderly women with hip and spine fractures. Journal of Clinical Endocrinology and Metabolism 199274 24-27.

21 Pun KK, Lau P, Wong FH, Cheng CL, Pun WK, Chow SP \& Leong JC. 25-Hydroxycholecalciferol and insulin-like growth factor I are determinants of serum concentration of osteocalcin in elderly. Bone 199011 397-400.

22 Wuster C, Blum WF, Schlemilch S, Ranke MB \& Ziegler R. Decreased serum levels of insulin-like growth factors and IGF binding protein 3 in osteoporosis. Journal of Internal Medicine $1993234249-255$.

23 Glauber HS, Vollmer WM, Nevitt MC, Ensrud KE \& Orwoll ES. Body weight versus body fat distribution, adiposity, and frame size as predictors of bone density. Journal of Clinical Endocrinology and Metabolism $1995801118-1123$.

24 Felson DT, Zhang Q, Hannan MT \& Anderson JJ. Effects of weight and body mass index on bone mineral density in men and women: The Framingham study. Journal of Bone and Mineral Research 1993 5 567-573.

25 Nuti R, Martini G \& Gennari C. Age-related changes of the whole skeleton and body composition in men. Calcified Tissue International $199557336-339$.

Received 13 October 1997

Accepted 22 January 1998 